\title{
Measuring Multi-Agency South Wales Police \\ Corruption: Implications of Evidence from Within
}

\author{
Prof Dr Paul James \\ Graduate School, Bangkok University \\ Klong-Toey, Rama 4 Road, Bangkok 10110 \\ E-mail: paul.j@bu.ac.th
}

Received: Sep. 2, 2019 Accepted: Sep. 24, 2019 Online published: Oct. 4, 2019

doi:10.5296/jpag.v9i4.15576ＵRL: https://doi.org/10.5296/jpag.v9i4.15576

\begin{abstract}
Purpose: This is a research paper that is focused on the evaluation of ex-senior policing managers perceptions and experiences of corruption practices, raised issues and developments related to the South Wales Police service, UK.

Methodology: An interpretive methodology was utilised in order to help understand ex-senior police perceptions underpinning multi-agency corruption over a number of decades. The scope for this research were former senior police officers who experienced the results of corruption processes and outcomes during their working activities in South Wales Police service. The population of interest was made up of 15 former senior police officers, who worked in multi-site police stations across the designated police area. Interviews were conducted with ten (10) former senior police officers.

Findings: The research outcomes consisted of four (4) Key Themes - Police Administration, Police Command Conduct, Judicial Involvement and Oversight, ten (10) sub-Themes with 221 conversation targets.

Implications: The paper addresses a number of raised areas resulting out of the analysis of the narrative to establish outcomes as - Police Administration, Police Command Conduct, Judicial Involvement and Oversight - and the deliberated implications of corruption for the management of the South Wales Police service.

Originality: Very little research has been conducted in this area and the paper addresses some major concerns/responses and important difficulties related to reducing opportunities for corruption conducted by police officers in the South Wales policing area.
\end{abstract}

Keywords: Police, Corruption, Multi-agency, South Wales 


\section{Introduction}

The use of the term "corruption" appears to be changing within the language used in the literature (Hickman, et al., 2016). In this paper it is referred to as police behaviour involving aspects such as deliberate and calculated illegal and unethical personal behaviour resulting in manipulation and malfeasance characteristics of police activities (Punch, 1985). Corruption is also attributed to the material misuse of an official position, motivated by the protection of personal gain (Ivković, 2005a). Punch (2000) further eluded that the level of police integrity reflected a barometer of society's health as well as police legitimacy (Reiner, 2010). However, there appears to be much difficulty in creating a focused and acceptable definition (Sööt \& Rootalu, 2012; IPCC, 2011) but that the essential elements already eluded to about the police are consistent with their perceived special and venerable position in society (Punch, 2003). Further, underpinning police corruption are controllable factors such as consistent opportunity (Doig, 2012) and the personal and collective determination of which laws to apply (Marché, 2009) - even to police officers (Miller, 1998).

\section{Literature Review}

Characteristics of Police corruption have shown consistently that many aspects of their personal behaviour appear to revolve around power, greed, and status - where it is persistent and reoccurring (Punch, 2000). Much of the research focusing on police corruption has been from the victim's side, but this research orientation is directly from a senior police officer's perspective.

\subsection{Measuring Police Corruption}

Corruption in the UK police forces is not measured and therefore the level, mix and influence has not been adequately researched or tested (Jacobs, 1999; Klockars, et al., 2000). Further, this "vacuum" of data appears to reflect a public-service secretive and covert police culture (Newburn, 2015) wrapped within community-related overt security indications and concerns (Zedner, 2009). Wide-ranging corruption (Rose-Ackerman, 2000) focused on large-scale endemic corruption appears to be a possible explanation of why policy development and subsequent measurements designed to root out corruption in the public interest (Klitgaard, 1988) fails. Over many decades reported research has indicated that corruption was so widespread as to cover most police officers (Baueris, 1997; Barker, 1983). Not surprisingly, many police officers are extremely reluctant to report corruption they have seen, experienced or engaged in (Ivkovic, 2005a; Krauss, 1994; Mollen, 1994) as there is reluctance within the judiciary to prosecute (Anechiarico \& Jacobs, 1996) as well as a lack of willingness to intervene by civil entities (Moore \& Stephens, 1991). This shows the paradox of police governance (Jones, 2003). This reinforces the police force as a separate, secretive, professionally insular organisation (Home Secretary, 2013) and does little to provide transparent oversight or external governance or for some, an adequate level of accountability as utilised in all other government bodies spending public money. Even, when the police are found to have failed in their duties, they are assessed and evaluated by the police - The Independent Office of Police Conduct (IOPC, 2018) - which can only review a complaint, but not interfere with or review a criminal investigation. This indicates that the IOPC provides 
little scope for changing police corruption or matters directly concerning police operations. Consequently, the police service is deemed to be a secretive, non-transparent government funded organisation that operates on its own recognisance through operational decisions "...made in accordance with guidelines set by the Home Office" (IOPC, 2018). Thus, lack of transparency is an issue (Home Secretary, 2013).

Implementing policy that focuses on giving the police more powers appears counterproductive as the independent authorities cannot escape the closed culture of induced corruption behaviour from within (Chen, Devery \& Doran, 2003) - especially where the independent judiciary are concerned (Stevens, 1993). However, this requires to be seen in the light of the UK Prime Ministers statement that "The Government takes police integrity very seriously. It is at the heart of public confidence in the police and underpins our model of policing by consent" (WalesOnline, 2015). Consequently, this picture raises considerable issues about the vicariousness of the policing system and how it is managed. It further supports the notions indicated by Punch and Gilmour (2010) whom claim that police corruption occurs in all police forces representing a consistent and permanent feature or operational characteristic - which is in opposition to the IPCC (2012) outcomes - that the prevalence of corruption amongst police officers in England and Wales is not "widespread". However, the level and extent of corruption has not been identified (Jacobs, 1999).

\subsection{Police Corruption in South Wales, UK}

Police corruption can be formulated into nurtured, complex models of crime resulting from the misuse of policing authority (Weisburd, et al., 2000), which is not bounded by rank (Newburn, 1999) raising an antithesis to the notion of routine compliance (Robinson \& McNeill, 2008). However, in the years 2008-2011, 8542 corruption allegations were made to the then Independent Police Complaints Commission (IPCC, 2012). Only 3\% of the corruption allegations were independently reviewed and where $70 \%$ were allowed to be dealt with locally. Of these, 631 allegations were registered for police corruption in Wales with 206 in the South Wales police area (IPCC, 2012), with only 1 upheld (WalesOnline, 2013), but with no prosecutions where 3 were waived by the IPCC. The IPCC at the time, had a compliment of $33 \%$ that were former police officers - around 140/420. These have been witnessed, assessed and researched for a very long time (Porter \& Warrender, 2009). Further, in 2018, it was reported that nearly 30 police officers in Wales had been convicted in the courts charged through the anti-corruption unit (WalesOnline, 2018). However, for senior officers, no such outcomes appear to have been recorded.

Following the principle that leaders of organisations create the ethical climate (Tasdoven \& Kaya, 2014), no open research has been conducted in policing in England and Wales because of the resistance of the organisation to helping illuminate corruption and affecting organisational legitimacy (Neese, Ferrell \& Ferrell, 2005). Further, there is a scarcity of independent research that has focused on corruption within the South Wales Police Force, UK. Where reports have been made - which have been consistently suppressed - for example, Operation Tiberius for the Metropolitan Police Force (The Independent, 2014). This research is particularly focused on attempting to assess whether this is the case and to help illuminate 
corruption issues raised during the South Wales police service operations. The adopted research orientation reflects a reduced notion of Klockars, Ivkovich \& Haberfeld police integrity (1997), suitably involving a dualistic framework of prevention and control mechanisms through structural barriers (Drew, Mills \& Gassaway, 2007) within an unchanging, pervasive and normalised operating police culture (Ashforth, et al., 2007; Goldsmith, 1991). These two internal areas are considered part of the core-value system of checks and balances that constitute operational policing necessities.

Having raised these issues (Arksey \& O'Malley, 2005; Househ, 2011), this creates the context for the research question, In what ways is police corruption in the South Wales Police Force experienced in the operational management, direction and its subsequent administration?

\section{Methodology}

This work follows on from an exploratory study of Chief officer misconduct in policing across the UK (Hales et al., 2015) which found that chief officer misconduct was recognised but went unchallenged. Consequently, this informs the context and pervading culture within which the present study was conducted. Exploring police corruption is empirically socially different from other professions (Moran, 2005), and a qualitative inquiry appears to engender more effective illumination of the issues underpinning police corruption. As most indicators of corruption in the police force are subjective indicators (Lambsdorff, 2006) the research orientation therefore needs to discriminate more effectively the various issues (Hill, Thompson \& Williams, 1997; Walsh, White \& Young, 2008).

A semi-structured interview design was employed from a subjective knowledge perspective (Kvale, 1996) whilst exploiting an inductive approach (Glaser \& Strauss, 1967). The interviews were conducted with respondents that have specific and targeted interests and whom provide an appropriate element of context and flexibility (Cassell \& Symon, 2004).

Consequently, the research focus targets former police officers' direct personal assessments and opinions through material observations of policing practices (Sutton \& Austin, 2015) gained through more than 10 years of direct senior policing experience in wide-ranging, complex police working-environments located at independent police stations within the geographical scope of the South Wales Policing Area. Accordingly, a population frame of 15 was studied, made up of former senior police officers who had worked in multi-site police stations across the designated police area. These were considered specialist knowledge agents and actors (Benn et al., 2008; Sbaraini et al., 2011) as their opinions and experiences influenced operational practices, and the development and application of operational policing strategies and goals. A pilot study was carried out with three (3) respondents from the targeted population and excluded from the main interview process, which informed the language and logic of the interview (Kim, 2011) providing a rationalised questioning sequence to help guide the ongoing conversation (Rubin \& Rubin, 2005).

This pertinent population frame (Ritchie \& Lewis, 2003) delivered an initial means for appropriate controlled sampling assessment within clear boundaries (Coyne, 1997). Given 
that not all individuals in this frame were available for interview during the data capture sequence or were employed in the pilot study, a sampling frame of 10 was generated, where all targeted respondents were included (Fink, 2000), and no respondent was considered out of scope relative to the research orientation and requirements (Koerber \& McMichael, 2008). Therefore, and in line with the adopted qualitative approach (Bryman, 2012), the targeted respondents were specifically chosen as representative of the population of interest (Carman, 1990) and this was also reflected in the criteria of relevance and appropriateness (Creswell, 2009) and considered appropriate for this inquiry (Guest, Bunce \& Johnson, 2006; Sofaer, 1999) as well as empirically adequate (Spanos, 1990). This however, had no bearing on the research logic and reasoning (Crouch \& McKenzie, 2006).

Interviews were conducted in English and took approximately one hour. All interviews were recorded digitally after gaining explicit permission (Gill et al., 2008; Duranti, 2007) and were later transcribed verbatim using NVivo 11 (Bailey, 2008). Interviews followed a structured process where each respondent was asked the same set of questions (Gray \& Wilcox, 1995; James, 2014) - staggered with modified supplementary questioning (Balshem, 1991; Punch, 2014). To increase the confidence of the data (Curry, Nembhard \& Bradley, 2009; Munn et al., 2014), transcriptions were returned to each respondent (Harris \& Brown, 2010) for further observations, correction, addition or deletion and consequent return, utilising validated referral (Reeves \& Harper, 1981). Whole-process validity was achieved through connecting the research question to the research interest (Stenbacka, 2001). Each interview was coded initially and independently using the Acrobat software according to themes that appeared from the interview dialogue using open-coding (Glaser, 1992); Straus \& Corbin, 1990) leading to thematic analysis using NVivo 11 (Walsh, White \& Young, 2008). Consequently, no portion of any interview conversation/dialogue was left uncoded and the overall outcome represented the respondent's views and perspectives. NVivo 11 was further used to explore the Key and sub-themes by helping to integrate them from each respective interview (Harwood \& Garry, 2003) by capturing each respondent's observations across transcripts (Riessman, 1993) on each identified theme for further analysis (Ryan \& Bernard, 2003). The favoured approach for the analysis of the generated primary data was to use the stated research question as a funnel to deliver the outcome (based on Yin, 1994; Hammersley \& Atkinson, 2007). The research methodology was utilised to create the best possible description of the situation in question (James \& James, 2011). The application of the overall research methodology provides an acceptable level of construct validity (Healy \& Perry, 2000) where the terms of credibility and dependability are preferred in place of reliability by applying Guba's constructs (Guba, 1981) and leading to the Lincoln \& Guba (1985) notion of "progressive subjectivity".

\subsection{Illustration of Research Outcomes}

The research outcomes - Police Corruption - are indicated in Figure 1, below is based on a layered, cogitated dissemination (Reisman, 2008). The outcomes are also illustrated as indicated in Table 1 and consists of four (4) Key Themes - Police Administration, Police Command Conduct, Judicial Involvement and Oversight, with 221 conversation targets. The discussion focuses on the Key theme elements. The respondent's voice is revealed by the 
stated ad verbatim dialogue, reflecting the direct expression of the respondent's opinion (Cassell \& Symon, 2004), where the reporting format is informed by Gonzalez (2008) and also Daniels et al. (2007). Consequently, the explanations presented are considered internally coherent (Coombs, 2017) adding to the value of the consequent analysis whilst maintaining respondent confidentiality (Kaiser, 2009). The minimum responses for each identified sub-theme is as indicated in Table 1 , below.



Figure 1. Research Outcomes

Table 1. Research question, themes and discussion targets

\begin{tabular}{|c|c|c|}
\hline \multicolumn{3}{|l|}{ Research Question } \\
\hline \multicolumn{3}{|c|}{$\begin{array}{l}\text { In what ways is police corruption in the South Wales Police Force experienced in the } \\
\text { operational management, direction and its's subsequent administration? }\end{array}$} \\
\hline Key Themes & Sub-Themes & No. Refs \\
\hline \multirow[t]{2}{*}{ Police Administration } & Managerial Intent & 24 \\
\hline & Evidence Manipulation & 19 \\
\hline \multirow[t]{3}{*}{ Police Command Conduct } & Protectionism Issues & 17 \\
\hline & Collusion & 29 \\
\hline & Duty of Conduct & 23 \\
\hline \multirow[t]{3}{*}{ Judicial Involvement } & Complicity with other Agencies & 26 \\
\hline & Abuse of Process & 21 \\
\hline & Crown Prosecution Service (CPS) & 13 \\
\hline \multirow[t]{2}{*}{ Oversight } & Lack of Independency & 33 \\
\hline & Illegal Partnerships & 16 \\
\hline
\end{tabular}

The major themes and respondents are underpinned by appropriate respondent statement views and its meaningful representation (James \& James, 2011) meeting the expected level of trustworthy criteria (Nowell et al., 2017) as indicated in Table 2, below. 
Table 2. Major themes and respondent citations

\begin{tabular}{|l|l|}
\hline Major Themes & Cited Respondent Number \\
\hline Police Administration & 3,7 \\
\hline Police Command Conduct & $1,4,8$ \\
\hline Extra-Judicial Involvement & $2,5,10$ \\
\hline Oversight & 6,9 \\
\hline
\end{tabular}

\section{Results}

The results are presented below, using the research question as a pointer and supportive empirical evidence through indicated extractions as in Gonzalez, (2008). Consequently, considering the research question - In what ways is police corruption in the South Wales Police Force experienced in the operational management, direction and its subsequent administration? The results are stated here as four (4) Key themes - Police Administration, Police Command Conduct, Judicial Involvement and Oversight; and ten (10) sub-themes as indicated in Table 1 and 2 (Appendix), where each sub-theme theme is placed with each corresponding Key theme.

Key Theme - Police Administration:

In terms of Managerial Intent this is typified by one respondent (7) who suggested that, ...We have seen files that show how a policeman was framed for assault by senior officers because he had found out about the police collusion in a case. It never changes, many people including police officers have become victims to these criminals. ... (Pol. Inspector).

In terms of Evidence Manipulation this is typified by one respondent (3) who advised that, ...I don't understand them, they have systematically tampered with evidence with impunity, note suppression, violations of suspects rights and even orchestrated the substitution of written confessions. But when questioned, they have all been over-ridden by a very senior officer. This was how it was... (Det. Inspector)

Key Theme - Police Command Conduct:

In terms of Protectionism Issues this is typified by one respondent (4) who tendered that, ...Why is it that these senior policemen don't get caught? It is beyond me. What surprises me is that if I can see it while doing my everyday job, so should others and that means many officers turning a blind eye to such criminal behaviour... (Pol. Inspector).

In terms of Collusion this is typified by one respondent (8) who put forward that, ...They do it all the time. They are a gang of thieves and thugs. They only protect themselves not the public. If you sack them all, you will literally have no police force left. It is sad, very sad. I cannot believe that they are still operating... (Pol. Chief Inspector).

In terms of Duty of Conduct this is typified by one respondent (1) who suggested that, ...Yes, I can recollect that at one time, the Superintendent at Pontypridd gave me orders to arrest a serving police officer for reporting a crime. I believe it was initiated from a serving Sergeant who was operationally indebted to them. But there was nothing I could do. I worked hard at 
my job and it was destroyed by senior police managers who were making sure you couldn't do your job properly and independently. One rule for them, I suppose... ... (Det. Sergeant).

Key Theme - Extra-Judicial Involvement:

In terms of Complicity with other Agencies this is typified by one respondent (10) who indicated that, ...It is very clear that often-unclear prosecutions are driven through the courts where magistrates show unacceptable derision of evidence and make decisions against innocent people. I was thinking at the time that this magistrate was surely going to release the man, given the evidence, but no he was convicted. They are just as crooked as the corrupt police standing before them... (Pol. Sergeant).

In terms of Abuse of Process this is typified by one respondent (5) who specified that, ...Of course, it's the truth. A Police Superintendent's son was involved in a lot of illegal stuff and this was meticulously researched by one police officer, who went to the boy's father with the evidence. Unfortunately, a gang of individuals beat him up, and they framed him. He was convicted of assault and forced to leave the police. It is difficult to know how the magistrate accepted their side unless he was paid... (Pol. Inspector)

In terms of Crown Prosecution Service (CPS) this is typified by one respondent (2) who offered that, ...They are supposed to be independent. However, they can only make decisions on what evidence is given to them, not what is withheld or substituted - even when they know the evidence has been tampered with. I cannot condone what they do, when marked envelopes get sent to only specific individuals at the CPS who make sure that "appropriate" treatments are conducted to make the "right" decision - which is always in-line with the corrupt Police needs. I know I did this too... (Det. Chief Inspector).

Key Theme - Oversight:

In terms of Lack of Independency this is typified by one respondent (9) who intimated that, ...it is perhaps a little difficult to accept, that so many good officers who reported wrong-doing relied on their independency. Unfortunately, when you know that your work is not always going to be as it was reported, eventually it makes you want to leave the force... (Pol. Sergeant).

In terms of Illegal Partnerships this is typified by one respondent (6) who advocated that, ...I have seen and witnessed large amounts of money being exchanged with solicitors or senior members of the CPS - it is easy to mess up any investigation, because of agreements to change stories, provide "additional" evidence or withhold/take evidence out of a case by senior police staff with lesser-ranked officers hoping to gain more later when they need a favour. But what can you do on your own?... (Pol. Chief Inspector).

\section{Discussion}

\subsection{Police Administration}

The data heavily suggests that the police appear to reflect a visible culture of impunity (Miller, 2016) often resulting in a continuing breach of confidentiality and trust (Punch, 2009b; 
Sampford, et al., 2006). This is coupled with intentional corruption, hiding of corruption and the protection of their positions to perform corruption and using organizational injustice (Reynolds \& Hicks, 2015; Greenberg, 1993) through social learning (Akers, 2009). It would appear from the data that they operate with a legal-rational authoritarian approach (Reiss, 1992) which represented their special place - to themselves - in the police community, where corrupt offers were made during their police experience, rather than being predisposed prior to engagement (Punch, 2003). This is seen as reflecting an uncompromising endemic system where newer police officers are exposed to deviant behaviour in order for them to accept this norm through direct behaviour transference (Howitt, 2002); Chappell \& Piquero, 2004).

Of further reported concerns were that many serving police officers appeared to ignore evidence and destroyed other evidence that showed such a conspiracy and that this was materially indicting for the SW Police force as a whole. This represents a deliberate policing management undertaking that ignored any existence of "sanctions" for police constituted crimes (Kahan, 1999) and subsequently nurtured the breakdown of ethical policing (Neyroud \& Beckley, 2001). Consequently, the engaged police corruption can be viewed as the responsibility of the organisational administration (King, 2009), but this is difficult to validate when the organisational managers are the individuals orchestrating such corruption matters.

\subsection{Police Command Conduct}

The data clearly indicated that police officers within these corrupt spheres of operation appear to be aggressive at keeping their status (Ivkovic, 2005b). This is also in relation to protecting police officers who commit very serious offences. In support of this assertion, the data also points to evidence-cash being used to create an extended "family" of enforcers - lower ranking police - to further the aims of higher-ranking police officers, solicitors and those within the judiciary colluding to operationalise the whole covert and systemic process. This form of "illegal regulation" (theconversation.com, 2017) from senior officers (Hales et al., 2015) for example, where reported acts of stealing from drug dealers contributes to the notion of uncontrolled and organised cartels, rather than functioning responsibly - as police officers.

Where corruption claims were investigated, they appear to have been deflected by higher command personnel to be assessed locally (IPCC, 2012). There was therefore a continuing culture of Police Command deceit (Reiner, 2010; Hales et al., 2015) that was focused on preventing detection, engagement of group mentality through General System Justification (Kay \& Jost, 2003) supported by a collective social dominance orientation (Tan, et al., 2016) through an embedded and fabricated shared reality (Jost, Ledgerwood \& Hardin, 2008). This reflected a consistent approach by police officers to ignoring their duty of conduct.

\subsection{Extra-Judicial Involvement}

The data has indicated clearly that agencies in the judicial arena (external corruption - Miller, 2003) - such as the CPS and solicitors - had been involved in "managing" the process to ensure that police directions were followed (Porter, 2005). The data has also suggested there 
was complicity with other "independent agencies that included defence solicitors - where presumably the defendant was unaware of such collusion, thus obviating due process (Tamanaha, 2004). Consequently, the use of such involvements could be classed as "extra-judicial acts" as it falls out of the predetermined scope of proper judicial operations and should be recognised as such. This leads to notions of abuse of process (CPS, 2018; Rose-Ackerman, 2000). This may also provide the basis for covering up even cases that had been meticulously put together and where during the reporting, advice, charging and prosecution phases, that evidence was manipulated (Punch, 2000). Given the raised issue involving the CPS in systemic acts of non-disclosure to the courts (The Guardian, 2018; The Telegraph, 2018; The Guardian, 2019), this has ramifications for the judiciary operations in terms of reliability and credibility (Fouzder, 2018). It also is a serious issue because without effective judicial operations, no corruption claims can get to court or be made public. Significantly, the data further suggested that at times an officer was always in a position to manipulate when and whom a case would be presented at court, so that a specific case could be placed to be in front of someone from the "circle". These very real acts of collusion appear to underpin the corruption influence that is seemingly ignored in the ongoing assessment of SW police service corruption investigations.

The research data shows that normative compliance measures (Tyler, 2011) reflect materially on the officers operating within the boundaries of police/social dynamics whilst opposing those seeking to illuminate their corrupt behaviour (Punch, 2000). Consequently, corruptive practices do not appear to be reduced by judicial deterrents (Pratt et al., 2006) and even provide an "irresistible loci" for corrupt policing actions (Wikstrom et al., 2010). Further, procedural justice (Tonry, 2007) which is central to police legitimization (Tyler, 2006) does not appear to be characterised positively as procedures depend entirely on the chain of evidence and custody being untampered with and methodologically coherent and preserved or maintained (Punch, 2009a).

\subsection{Oversight}

The data indicates a lack of engagement in proper oversight and laying claim to an absence of critical independency (Langseth, 2006) within the South Wales Police service. This has resulted in public erosion of trust, through expectancies of procedural justice (Tyler, 2003) especially when considering that police offers are highly trained in applying procedural judgements through rational policing legitimacy (Murphy, Tyler \& Curtis, 2009) within a code-based justice system (Dzhekova, Gounev \& Bezlov, 2013). The evidence further points to a police service fraught with difficulties and a core culture associated with a systemic operationalised criminality (Granovetter, 2007) relating to corruption and its associated social justice concerns of fairness and equity (Tyler, 2000). The real level of integrity (Kaptein \& van Reenen, 2001), resulting from a lack of transparency (Bayley, 2001; Schafer, 2013) and ineffective police integrity judgements (Ransley, 2002), appears to promote a misplaced loyalty reflecting the "Blue-Code" (Skolnick, 2002), fostering concerns over ineffective and inappropriate policing governance (Edwards, 2005) and thus raising a lack of confidence in the South Wales police force and other concomitant operating agencies. 
The data suggests clearly that covert illegal partnerships between police members and external stakeholders were consistently in operation and often as support to the corruption occurring during "normal" policing operations. However, and more worryingly, was the reported expectancy associated with what was being done with little feedback from anyone in the external information stream that anything was wrong. This was convincing, as the oversight of such a system showed only tenuous engagement, competitive inclinations and a complete lack of real authority and guided autonomy. This is especially of concern when anti-corruption and police standards units are amalgamated resulting in compromised data, processes and possibilities. Of further concern was the stated inadequate planning by senior police to address appropriate police training in the criminal justice system (HMICFRS, 2017) which could explain obscured corruption through inadequate justice process governance. This outcome appears to be in direct contrast to the requirements for active co-operation and decision-making reflecting the evidence, integrity and good prosecution/policing protocols (HMIC, 2015).

\section{Conclusions}

Corruption in the South wales Police force appears to be highly substantiated when research points towards those involved - former police officers. However, first-hand accounts of police corruption indicate clearly the level of reprehensible behaviour which appears to be a consistent issue and remains unchecked within its closed, punitive culture (Skolnick, 2002). Collusion appears to be the "irrational norm" (Anand, Ashforth \& Joshi, 2004) indicating that such corrupt behaviour has been well ingrained and supported both inside the police command and in external agencies in the judiciary and other related police-connected agencies and where reporting of misconduct is seen as an operational and cultural weakness (Ivkovic, 2005b) leading to non-aligned failings associated with the cost of procedural justice (Miller, 2016; Cohen-Charash \& Spector, 2001). Thus, the operating culture (Skolnick, 2002; Garcia, 2005) has not been sufficiently mobilised in a direction to counter or be intolerant of, corruption which is irrespective of the political and social/moral agenda associated with police powers and policing governance (Prenzler, 2009). Consequently, the police, as an organisation, does not suffer any material cost associated with reducing corruption activities, except in terms of "outside" perceptions of credibility. Other than political overtones, the South Wales police organisation is also perceived by many as immune to whether corruption continues or is abated which socially undermines public support (Tyler \& Huo, 2002). Thus, there is little, if any, movement towards building organisational credibility and upholding its legitimacy by ineffective perceptions of organisational justice (Myhill \& Bradford, 2013).

From 8542 police corruption claims in the UK and 13 successful prosecutions; and 631 in the South Wales Police area; and with 1 corruption claim upheld - both persuading a statistical significance (2008-2012). This is unrealistic and therefore its treatment is seen as being significantly affected by deliberate extraneous outcomes (James, 2005) or the corruption claims raises the issue of barriers to investigations and the lack of transparency from within the police service (Schafer, 2013). One further outcome of this is that the police appear incapable of managing the evidence/charging/prosecution process - clearly for the majority of corruption claims in the UK $(99.992 \%)$ that would be the consequence. This is also a raised 
issue for other crimes (The Guardian, 2018; The Guardian, 2019). This result challenges police and judicial credibility (Punch, 2009b) and also raises covert issues associated with why the data and decisions from investigations cannot be made public. This is of exceptional concern since it involves a publicly funded organisation and reflects a public policy issue (Sampford, et al., 2006) as it is the police who directly control the data and the police processes associated with its generation, storage, access and retainment.

With the reported lack of appropriate oversight and the introverted police-power in terms of self-protection and operating culture (Skolnick, 2002), it is difficult to see how the SW police force can reduce such corruption irrespective of their collective moral responsibility (Miller, 2006) to meet the required oversight standards (HMIC, 1999). Consequently, the police do not appear to be in a position to effectively review and make internal changes, and this raises the possibility of using a separate civil security force could be utilised to provide the level of independent review engagement in order to modify the structural code and authentic operational requirements (Loader \& Walker, 2006).

Corruption in the police force could be better assessed if this type of unlawful activity was considered a hate crime (Sharrock, et al, 2018). In this respect, the hate crime would be because the individuals carrying out the corruption do so without thought to the victim's consequences and costs the police force in terms of effectiveness, adequacy and the positive perception by the public. This, therefore suggests the inherent need for reform (Prenzler \& Ransey, 2002) and more streamlined, informed and necessary governance and accountability requirements beyond just politically derived data (Chapman, 1970). However, developing more effective means to assess and transform policing practices in South Wales would require more than just conducting system audits of recorded incident data (Prenzler, 2009) or external operating integrity assessments (Hoque, Arends \& Alexander, 2004). Consequently, utilising policing surveys (Ede \& Legosz, 2002) does very little as they project unsupported and unsubstantiated opinion lacking in authoritive scope, reliability and significance (Klockars, et al., 2000). Further, the literature neglects to research the application of the organisational injustice concept (Trinkner, Tyler \& Goff, 2016) nor social learning theory (Chappell \& Piquero, 2004) to help illuminate the level and prevalence of police misconduct (Moran, 2005; Brown, 2006). However, much research cannot be done effectively because of demonstrated lack of access under the notion of "security" to real data collected by police during their inquiries and the application of internal decision-making processes (Kane, 2002).

This work also raises questions about the efficacy of past research and its espoused levels of corruption, and lack of corruption risk management statements (Sampford, et al., 2006) which do not appear to represent the true reality as found in the South Wales Police service. Social justice leadership (Theoharis, 2007) is lacking in the mandate of the SW police service and more research is needed to help discover how this can be remedied as those victims of such abuse require more positive organisational changes.

Given the level, type and breadth of the reported corruption within the South Wales Police service, it is unlikely that all judgements in the courts can be considered fair and free from operational corruption influences and raise considerable ethical, reliability, confidence and 
trust issues regarding everyday policing operations conducted in South Wales, UK.

\section{References}

Akers, R. (2009). Social learning and social structure: A general theory of crime and deviance. New Brunswick: Transaction. https://doi.org/10.1007/978-1-4419-0245-0_6

Anand, V., Ashforth, E. \& Joshi, M. (2004). Business as usual: The acceptance and perpetuation of corruption in organisations. Academy of Management Executive, 18(2), 39-53. https://doi.org/10.5465/ame.2004.13837437

Anechiarico, F., \& Jacobs, J. (1996). The pursuit of absolute integrity: How corruption control makes government ineffective. Chicago: University of Chicago Press.

Ashforth, B., Kreiner, G., Clark, M., \& Fugate, M. (2007). Normalizing Dirty Work: Managerial Tactics for Countering Occupational Taint. Academy of Management Journal, 50(1), 149-174. https://doi.org/10.5465/amj.2007.24162092

Bailey, K. (2008). Methods of Social Research. New York: The Free Press.

Balshem, M. (1991). Cancer, Control and Causality: Talking about Cancer in a Working-Class Community. American Ethnologist, 18(1), 152-172. https://doi.org/10.1525/ae.1991.18.1.02a00070

Barker, T. (1983). Rookie police officers' perceptions of police occupational deviance. Police Studies, 6(2), 30-38.

Baueris, V. (1997). New York Police Department: Preventing crime and corruption. [Online] Available: http://www.icac.nsw.gov.au/files/pdf/pub2_30cp.pdf (May 17, 2019)

Bayley, D. (2001). Democratizing the police abroad: What to do and how to do it. Washington DC: National Institute of Justice, Washington DC.

Benn, N., Buckingham, S., Domingue, J., \& Mancini, C. (2008). Ontological Foundations for Scholarly Debate Mapping Technology. In 2nd International Conference on Computational Models of Argument (COMMA '08), Toulouse, France.

Brown, A. (2006). What are We Trying to Measure? Reviewing the Basics of Corruption Definition - Chap 4, Part 1. In: Sampford, C., Shacklock, A., Connors, C., \& Glatung, F. (Eds.) Measuring Corruption. Hampshire: Ashgate.

Bryman, A. (2012). Social Research Methods. Oxford University Press: Oxford, UK.

Carman, J. (1990). Consumer Perceptions of Service Quality: An Assessment of the SERVQUAL Dimensions. Journal of Retailing, 66(1), 33-55.

Cassell, C., \& Symon, G. (2004). Essential Guide to Qualitative Methods in Organizational Research. London: Sage Publications. https://doi.org/10.4135/9781446280119

Chapman, B. (1970). Police State. London: Pall Mall Press. https://doi.org/10.1007/978-1-349-00944-2 
Chappell, A., \& Piquero, A. (2004). Applying social learning theory to police misconduct. Deviant Behavior, 25, 85-108. https://doi.org/10.1080/01639620490251642

Chen, J., Devery, C., \& Doran, S. (2003). Fair cop: Learning the art of policing. Toronto: University of Toronto Press. https://doi.org/10.3138/9781442674783

Cohen-Charash, Y., \& Spector, P. (2001). The role of justice in organizations: A meta-analysis. Organizational Behavior and Human Decision Processes, 86, 278-321. https://doi.org/10.1006/obhd.2001.2958

Coombes, C. (2017). Coherence and transparency: some advice for qualitative researchers. Production, 27. https://doi.org/10.1590/0103-6513.006817

Coyne, I. (1997). Sampling in qualitative research: purposeful and theoretical sampling; merging or clear boundaries? Journal of Advanced Nursing, 26(3), 623-630. https://doi.org/10.1046/j.1365-2648.1997.t01-25-00999.x

$\begin{array}{llll}\text { CPS. } & \text { (2018). Abuse } & \text { Process. }\end{array}$

Available: https://www.cps.gov.uk/legal-guidance/abuse-process (March 14, 2019)

Creswell, J. (2009). Research design: Qualitative, quantitative, and mixed methods approaches. London: Sage Publications.

Crouch, M., \& McKenzie, H. (2006). The logic of small samples in interview-based qualitative research. Social Science Information, 45(4), 483-499. https://doi.org/10.1177/0539018406069584

Curry, L., Nembhard, I., \& Bradley, E. (2009). Qualitative and mixed methods provide unique contributions to outcomes research. Circulation. 119(10), 1442-1452. https://doi.org/10.1161/CIRCULATIONAHA.107.742775

Daniels, J., Bradley, M., Cramer, D., Winkler, A., Kinebrew, K., \& Crockett, D. (2007). The Successful Resolution of Armed Hostage/Barricade Events in Schools: A Qualitative Analysis. Psychology in the Schools, 44(6), 601-613. https://doi.org/10.1002/pits.20250

Doig, A. (2012). Conclusion to the Special Issue: Time to consider prevention as well as retribution? Public Administration and Development, 3(2), 129-135. https://doi.org/10.1002/pad.1606

Drew, S., Mills, M., \& Gassaway, B. (2007). Dirty Work. Waco: Baylor University Press.

Duranti, A. (2007). Transcripts, like Shadows on a Wall. Mind, Culture, and Activity, 13(4), 301-310. https://doi.org/10.1207/s15327884mca1304_3

Dzhekova, R., Gounev, P., \& Bezlov, T. (2013). Countering Police Corruption: European Perspectives. Sofia: Center for Study of Democracy.

Ede, A., \& Legosz, M. (2002). Monitoring the ethical climate of organizations: A Queensland case study. Crime and Misconduct Commission research and Issues paper, 2. Brisbane: Crime and Misconduct Commission. 
Edwards, A. (2005). Governance. In: McLaughlin, E. \& Muncie, J. (Eds), The Sage Dictionary of Criminology. London: Sage Publications.

Fink, A. (2000). The Role of the Researcher in the Qualitative Research Process. A Potential Barrier to Archiving Qualitative Data. Forum: Qualitative Social Research, 1(3), article 4. [Online] Available: http://nbn-resolving.de/urn:nbn:de:0114-fqs000344 (April 14, 2019)

Fouzder, M. (2018). Attorney general must explain CPS disclosure failings. The Law Society Gazette.

[Online]

Available: https://www.lawgazette.co.uk/news/attorney-general-must-explain-cps-disclosure -failings/5066884.article (13 ${ }^{\text {th }}$ April 2019)

Garcia, V. (2005). Constructing the "Other" within Police Culture: An Analysis of a Deviant Unit within the Police Organisation. Police Practice and Research, 6, 65-80.

Gill, P., Stewart, K., Treasure, E., \& Chadwick, B. (2008). Methods of data collection in qualitative research: interviews and focus groups. British Dental Journal, 204, 291-295. https://doi.org/10.1038/bdj.2008.192

Glaser, B. (1992). Basics of Grounded Theory Analysis. Mill Valley: Sociology Press.

Glaser, B., \& Strauss, A. (1967). The Discovery of Grounded Theory: Strategies for Qualitative Research. Chicago: Aldine. https://doi.org/10.1097/00006199-196807000-00014

Goldsmith, A. (1991). Complaints Against the Police: The Trend to External Review. Oxford: Oxford University Press.

Gonzalez, C. (2008). Conceptions of, and approaches to, teaching online: a study of lecturers teaching postgraduate distance courses. Higher Education, 57(3), 299-314. https://doi.org/10.1007/s10734-008-9145-1

Granovetter, M. (2007). The social construction of corruption. In: Nee, V., \& Swedberg, R. (Eds), On capitalism. Stanford: Stanford University Press.

Gray, J., \& Wilcox, B. (1995). Good Schools, Bad Schools. Buckingham: Open University Press.

Greenberg, J. (1993). The Social Side of Fairness: Interpersonal and Informational Classes of Organizational Justice. In: Cropanzano, R., Ed., Justice in the Workplace: Approaching Fairness in Human Resource Management. Hillsdale: Lawrence Erlbaum Associates.

Guba, E. (1981). Criteria for assessing the trustworthiness of naturalistic inquiries. Educational Technology Research and Development, 29, 75. https://doi.org/10.1007/BF02766777

Guest, G., Bunce, A., \& Johnson, L. (2006). How Many Interviews Are Enough?: An Experiment with Data Saturation and Variability. Field Methods, 18(1), 59-82. https://doi.org/10.1177/1525822X05279903

Hales, G., May, T., Belur, J., \& Hough, M. (2015). Chief officer misconduct in policing: An 
exploratory study. College of Policing. [Online] Available: http://whatworks.college.police.uk/Research/Pages/Published.aspx (July 5, 2019)

Hammersley, M., \& Atkinson, P. (2007). Ethnography: Principles in Practice. Abingdon: Routledge. https://doi.org/10.4324/9780203944769

Harris, L., \& Brown, G. (2010). Mixing interview and questionnaire methods: Practical problems in aligning data. Practical Assessment, Research and Evaluation, 15(1), 1-19.

Harwood, T., \& Garry, T. (2003). An Overview of Content Analysis. The Marketing Review, 3(4), 479-498. https://doi.org/10.1362/146934703771910080

Healy, M., \& Perry, C. (2000). Comprehensive criteria to judge validity and reliability of qualitative research within the realism paradigm. Qualitative Market Research: An International Journal, 3(3), 118-126. https://doi.org/10.1108/13522750010333861

Hickman M., Piquero, R., Zachary A., \& Greene, J. (2016). Expanding the measurement of police integrity. Policing: An International Journal of Police Strategies and Management, 39(2), 246-267. https://doi.org/10.1108/PIJPSM-09-2015-0104

Hill, C., Thompson, B., \& Williams, E. (1997). A guide to conducting consensual qualitative $\begin{array}{llll}\text { research. The } & \text { Counseling 25(4), } & \text { 5 }\end{array}$ https://doi.org/10.1177/0011000097254001

HMIC. (1999). Police Integrity England, Wales and Northern Ireland. Securing and Maintaining Public Confidence. London: HMIC.

HMIC. (2015). Integrity matters: An inspection of arrangements to ensure integrity and to provide the capability to tackle corruption in policing. [Online] Available: www.justiceinspectorates.gov.uk/hmic (March 13, 2019)

HMICFRS. (2017). State of Policing - The Annual Assessment of Policing in England and Wales 2017. [Online] Available: https://www.justiceinspectorates.gov.uk/hmicfrs/wp-content/uploads/state-of-policing-2017-2 .pdf (February 18, 2019)

Home Secretary. (2013). House of Commons Official Report, 12 February 2013, Column 713. [Online] Available: www.parliament.uk (January 25, 2019)

Hoque, Z., Arends, S., \& Alexander, R. (2004). Policing the police service: A case study of the "new public management" within an Australian police service. Accounting, Auditing and Accountability Journal, 17(1), 59-84. https://doi.org/10.1108/09513570410525210

Howitt, D. (2002). Forensic and criminal psychology. London: Prentice Hall.

IOPC. (2018). [Online] Available: https://www.policeconduct.gov.uk/ (August 13, 2019)

IPCC (2011). Corruption in the Police Service in England and Wales - First Report. Retrieved [Online] Available: http://www.ipcc.gov.uk/Documents/Corruption_in_the_Police_Service_in_ 
England_Wales.pdf (August 4, 2019)

IPCC. (2012). Corruption in the police service in England and Wales: Second report - a report based on the IPCC's experience from 2008 to 2011. London: HMSO.

Ivkovic, S. (2005a). Fallen Blue Knights: Controlling Police Corruption. Oxford: Oxford University Press.

Ivkovic, S. (2005b). To serve and collect: measuring police corruption. Journal of Criminal Law and Criminology, 93(2/3), 593-650.

Jacobs, B. (1999). Dilemmas of corruption control. Perspectives on Crime and Justice 1998-1999 lecture series before the Department of Justice, National Institute of Justice, Washington DC. [Online] Available: http://www.ncjrs.org/pdffiles 1/nij/178244.pdf (August 22, 2019).

James, P. (2005). Total Quality Management in Asia: Practices for the 21st Century. Singapore: Pearson.

James, P. (2014). Managerial Challenges Impacting on Contractor Led Tunnel TBM Design: A Kingdom of Saudi Arabia Metro Project. Engineering Management Research, 3(2), November, 2014. https://doi.org/10.5539/emr.v3n2p32

James, P., \& James, T. (2011). Qualitative Research Methods for Health Services. London: Megellan UK Press.

Jones, T. (2003). The governance and accountability of policing, In: Newburn, T. (ed.), The Handbook of Policing. Cullompton: Willan Publishing.

Jost J., Ledgerwood A., \& Hardin C. (2008a). Shared reality, system justification, and the relational basis of ideological beliefs. Soc. Personal. Psychol. Compass, 2, 171-186. https://doi.org/10.1111/j.1751-9004.2007.00056.x

Kahan, D. (1999). The Secret Ambition of Deterrence. Harvard Law Review, 113, 413-500. https://doi.org/10.2307/1342330

Kaiser, K. (2009). Protecting Respondent Confidentiality in Qualitative Research. Qualitative Health Research, 19(11), 1632-1641. https://doi.org/10.1177/1049732309350879

Kane, R. (2002). The social ecology of police misconduct. Criminology, 40, 867-896. https://doi.org/10.1111/j.1745-9125.2002.tb00976.x

Kaptein, M., \& van Reenen, P. (2001). Integrity management of police organizations. Policing: An International Journal of Police Strategies and Management, 24(3), 281-300. https://doi.org/10.1108/13639510110401672

Kay, A., \& Jost, J. (2003). Complementary justice: effects of "poor but happy" and "poor but honest" stereotype exemplars on system justification and implicit activation of the justice motive. J Pers Soc Psychol., 85(5), 823-37. https://doi.org/10.1037/0022-3514.85.5.823

Kim, Y. (2011). The Pilot Study in Qualitative Inquiry: Identifying Issues and Learning 
Lessons for Culturally Competent Research. Qualitative Social Work, 10(2), 190-206. https://doi.org/10.1177/1473325010362001

King, W. (2009). Police officer misconduct as normal accidents: An organizational $\begin{array}{lllll}\text { perspective. Criminology and Public Policy, 8, } & \text { 771-776. }\end{array}$ https://doi.org/10.1111/j.1745-9133.2009.00592.x

Klitgaard, R. (1988). Controlling Corruption. Berkeley: University of California Press.

Klockars, C., Ivkovich, S., Harver, W., \& Haberfeld, M. (2000). The measurement of police integrity. Department of Justice, Washington DC: National Institute of Justice, Washington DC. https://doi.org/10.1037/e526382006-001

Klockars, K., Ivković, S., \& Haberfeld, M. (1997). The measurement of police integrity. Final report. Department of Justice. Washington DC: National Institute of Justice, Washington DC.

Klockars, K., Ivković, S., \& Haberfeld, M. (2003). The contours of police integrity. London: Sage Publications.

Koerber, A., \& McMichael, L. (2008). Qualitative Sampling Methods: A Primer for Technical Communicators. Journal of Business and Technical Communication, 22(4), 454-473. https://doi.org/10.1177/1050651908320362

Krauss, C. (1994, June 19). Poll finds a lack of faith in the police. The New York Times, A1. [Online] Available: https://www.nytimes.com/1994/06/19/us/poll-finds-a-lack-of-faith-in-police.html (June 7, 2019)

Kvale, S. (1996). Interviews: An Introduction to Qualitative Research Interviewing. Thousand Oaks: Sage Publications. https://doi.org/10.1016/0147-1767(85)90062-8

Lambsdorff, J. (2006). Measuring Corruption - The Validity and Precision of Subjective Indicators (CPI) - Chap 5, Part 1, In: Sampford, C., Shacklock, A., Connors, C., \& Glatung, F. (Eds.). Measuring Corruption. Hampshire: Ashgate.

Langseth, P. (2006). Measuring Corruption - Chap 2, Part 1. In: Sampford, C., Shacklock, A., Connors, C., \& Glatung, F. (Eds.). Measuring Corruption. Hampshire: Ashgate.

Lincoln, Y., \& Guba, E. (1985). Naturalistic Inquiry. Beverly Hills: Sage Publications.

Loader, I., \& Walker, N. (2006). Necessary Virtues: The Legitimate Place of the State in the Production of Security, In: Wood, J., \& Dupont, B. (Eds.) Democracy, Society and the Governance of Security. Cambridge: Cambridge University Press.

Marché, G. (2009). Integrity, culture, and scale: an empirical test of the big bad police agency. Crime, Law and Social Change, 15, 463-486. https://doi.org/10.1007/s10611-008-9184-7

Miller, S. (1998). Authority, Discretion and Accountability: The Case of Policing. In: Sampford, C., \& Preston, N, Public sector ethics: finding and implementing values. London: Routledge. 
Miller, S. (2003). Police Corruption in England and Wales: An Assessment of Current Evidence. Home Office Online Report 11/03. London: Home Office. [Online] Available: http://www.homeoffice.gov.uk/rds/pdfs2/rdsolr1103.pdf (August 22, 2019)

Miller, S. (2006). Collective moral responsibility: An individualist account. Midwest Studies in Philosophy, 30, 176-193. https://doi.org/10.1111/j.1475-4975.2006.00134.x

Miller, S. (2016). Corruption and Anti-Corruption in Policing - Philosophical and Ethical Issues. Oxford: Springer. https://doi.org/10.1007/978-3-319-46991-1

Mollen, M. (1994). Commission to Investigate Allegations of Police Corruption and the Anti-Corruption Procedures of the New York City Police Department. New York: The Commission.

Moore, M., \& Stephens, D. (1991). Organization and management. In: Geller, W. (Ed.), Local government police management. Washington DC: International City Management Association.

Moran, J. (2005). 'Blue walls', 'grey areas' and 'cleanups': Issues in the control of police corruption in England and Wales. Crime, Law and Social Change, 43, 57-79. https://doi.org/10.1007/s10611-005-3003-1

Munn, Z., Porritt, K., Lockwood, C., Aromataris, E., \& Pearson, A. (2014). Establishing confidence in the output of qualitative research synthesis: the ConQual approach. BMC Medical Research Methodology, 14, 108. https://doi.org/10.1186/1471-2288-14-108

Murphy, K., Tyler, T., \& Curtis, A. (2009). Nurturing Regulatory Compliance: Is Procedural Justice Effective when People Question the Legitimacy of the Law? Regulation and Governance, 3, 1-26. https://doi.org/10.1111/j.1748-5991.2009.01043.x

Myhill, A., \& Bradford, B. (2013). Overcoming cop culture? Organizational justice and police officers' attitudes toward the public. Policing: An International Journal of Police Strategies and Management, 36, 338-356. https://doi.org/10.1108/13639511311329732

Neese, W., Ferrell, L., \& Ferrell, O. (2005). An analysis of federal mail and wire fraud cases related to marketing. Journal of Business Research, 58(6), 910-918. https://doi.org/10.1016/j.jbusres.2004.01.010

Newburn, T. (1999). Understanding and Preventing Police Corruption: Lessons from the literature. London: Home Office.

Newburn, T. (2015). Literature review - Police integrity and corruption. HMIC. [Online] Available:

https://www.justiceinspectorates.gov.uk/hmicfrs/wp-content/uploads/pic-literature-review.pdf (June 23, 2019)

Neyroud, P., \& Beckley A. (2001). Policing, Ethics and Human Rights. London: Routledge. https://doi.org/10.4324/9781843924678

Nowell, L., Norris, J., White, D., \& Moules, N. (2017). Thematic Analysis: Striving to Meet 
the Trustworthiness Criteria. International Journal of Qualitative Methods, 16(1). https://doi.org/10.1177/1609406917733847

Porter, L. (2005). Policing the police service: Theoretical and practical contributions of psychologists to understanding and preventing corruption. In: Alison, L. (Ed.), A forensic psychologist's casebook: Psychological profiling and criminal investigation. Cullompton: Willan Publishing.

Porter, L., \& Warrender, C. (2009). A multivariate model of police deviance: examining the nature of corruption, crime and misconduct. Policing and Society: An International Journal of Research and Policy, 19(1), 79-99. https://doi.org/10.1080/10439460802457719

Pratt, T., Cullen, F., Blevins, K., Daigle, L., \& Madsen, T. (2006). The Empirical Status of Deterrence Theory: A Meta-Analysis. In: Cullen, et al., (Eds), Taking Stock: The Status of Criminological Theory. London: Transaction Publishers.

Prenzler, T. (2009). Police Corruption, Preventing Misconduct and Maintaining Integrity. London: CRC Press. https://doi.org/10.1201/9781420077971

Prenzler, T., \& Ransey, J. (2002). Police Reform: Building Integrity. Sydney: Hawkins Press.

Punch, K. (2014). Introduction to Social Research: Quantitative and Qualitative Approaches. London: Sage Publications.

Punch, M. (1985). Conduct Unbecoming: The social construction of police deviance and control. London: Tavistock.

Punch, M. (2000). Police Corruption and Its Prevention. European Journal on Crime Policy and Research, 8, 301-324. https://doi.org/10.1023/A:1008777013115

Punch, M. (2003). Rotten Orchards: "Pestilence", Police Misconduct and System Failure. Policing and Society, 13(2), 171-196. https://doi.org/10.1080/10439460308026

Punch, M. (2009a). Police Corruption: Exploring Police Deviance and Crime. Cullompton: Willan Publishing.

Punch, M. (2009b). Police Corruption, Deviance, Accountability and Reform in Policing. Cullompton: Willan Publishing. https://doi.org/10.1093/police/paq053

Punch, M., \& Gilmour, S. (2010). Police corruption: apples, barrels and orchards. Criminal Justice Matters, 79(1), 10-12. https://doi.org/10.1080/09627250903569890

Ransley, J. (2002). Miscarriages of justice. In: Prenzler, T., \& Ransley J., Police reform: Building integrity. Sydney: Federation Press.

Reeves, T., \& Harper, D. (1981). Surveys at Work. London: McGraw-Hill.

Reiner, R. (2010). The Politics of the Police. Oxford: Oxford University Press. https://doi.org/10.1093/he/9780199283392.001.0001

Reisman, C. (1993). Narrative Analysis. London: Sage Publications. 
Reisman, C. (2008). Narrative methods for the human sciences. London: Sage Publications.

Reiss, A. (1992). Police organization in the twentieth Century. In: Tonry, M., \& Morris, N., Modern Policing. Chicago: University of Chicago Press.

Reynolds, P., \& Hicks, J. (2015). 'There is no justice in a police department': A phenomenological study of police experiences. Police Practice and Research, 16, 469-484. https://doi.org/10.1080/15614263.2014.931229

Ritchie, J., \& Lewis, J. (2003). Qualitative Research Practice: A Guide for Social Science Students and Researchers. London: Sage Publications.

Robinson, G., \& McNeill, F. (2008). Exploring the dynamics of compliance with community penalties. Theoretical Criminology, 431-449. https://doi.org/10.1177/1362480608097151

Rose-Ackerman, S. (2000). Democracy and grand corruption. In: Williams, R. (ed.), Explaining Corruption. London: Elgar Reference Collection.

Rubin, H., \& Rubin, I. (2005). Qualitative Interviewing: The Art of Hearing Data. Thousand Oaks: Sage Publications. https://doi.org/10.4135/9781452226651

Ryan, G., \& Bernard, H. (2003). Techniques to Identify Themes. Field Methods, 15(1), 85-109. https://doi.org/10.1177/1525822X02239569

Sampford, C., Shacklock, A., Connors, C., \& Galtung, F. (2006). Measuring Corruption. Aldershot: Ashgate Publishing.

Sbaraini, A., Carter, S., Evans, R., \& Blinkhorn, A. (2011). How to do a grounded study a worked example of a study of dental practices. BMC Medical Research Methodology, 11, 128. https://doi.org/10.1186/1471-2288-11-128

Schafer, J. (2013). The role of trust and transparency in the pursuit of procedural and organizational justice. Journal of Policing, Intelligence and Counter-Terrorism, 8, 131-143. https://doi.org/10.1080/18335330.2013.821738

Sharrock, S., Pullerits, M., Piggott, P., Edwards, S., \& DeMarco, J. (2018). The experiences of victims of hate crime. NatCen Social Research, October. Prepared for: Her Majesty's Inspectorate of Constabulary and Fire and Rescue Services, UK. [Online] Available: http://natcen.ac.uk/media/1622569/the-experiences-of-victims-of-hate-crime.pdf (April 4, 2019)

Skolnick, J. (2002). Corruption and the blue code of silence. Police Practice and Research, 3(1), 7-19. https://doi.org/10.1080/15614260290011309

Sofaer, S. (1999). Qualitative methods: What are they and why use them? Health Services Research, 34, 1101-1118. http://www.ncbi.nlm.nih.gov/pmc/articles/PMC1089055/

Sööt, M., \& Rootalu, K. (2012). Institutional trust and opinions of corruption. Public Administration and Development, 32, 82-95. https://doi.org/10.1002/pad.616 
Spanos, A. (1990). Towards a Unifying Methodological Framework. In: William, C., \& Granger, J., Readings in Econometric Methodology, Oxford: Clarendon Press.

Stenbacka, C. (2001). Qualitative research requires quality concepts of its own. Management Decision, 39(7), 551-556. https://doi.org/10.1108/EUM0000000005801

Stevens, R. (1993). The Independence of the Judiciary: The View from the Lord Chancellor's Office. Oxford: Oxford University Press.

Strauss, A., \& Corbin, J. (1990). Basics of Qualitative Research: Grounded Theory, Procedures and Techniques. Chicago: Sage Publications.

Sutton, J., \& Austin, Z. (2015). Qualitative research: data collection, analysis management. The Canadian Journal of Hospital Pharmacy, 68(3), 226-231. http://dx.doi.org/10.4212/cjhp.v68i3.1456

Tamanaha, B. (2004). On the Rule of Law. Cambridge: Cambridge University Press. https://doi.org/10.1017/CBO9780511812378

Tan, X., Liu, L., Huang, Z., Zheng, W., \& Liang, Y. (2016). The Effects of General System Justification on Corruption Perception and Intent. Frontiers in Psychology, 7, 1107. https://dx.doi.org/10.3389/fpsyg.2016.01107

Tasdoven, H., \& Kaya, M. (2014). The Impact of Ethical Leadership on Police Officers' Code of Silence and Integrity: Results from the Turkish National Police. International Journal of Public Administration, 37(9), 529-541. https://dx.doi.org/10.1080/01900692.2013.865649

The Guardian. (2018). CPS and police 'routinely failing' to disclose evidence. [Online] Available:

https://www.theguardian.com/law/2018/nov/15/cps-and-police-routinely-failing-to-disclose-e vidence (March 15, 2019)

The Guardian. (2019). Most police forces fail to meet fingerprint evidence standards. [Online] Available:

https://www.theguardian.com/science/2019/jan/07/police-forces-fail-to-meet-forensics-finger print-evidence-standards ( $7^{\text {th }}$ January 2019)

The Independent. (2014). Scotland Yard's rotten core: Police failed to address Met's 'endemic corruption'.

[Online]

Available: https://www.independent.co.uk/news/uk/crime/exclusive-scotland-yard-s-rotten-core-police-f ailed-to-address-endemic-corruption-9050224.html (May 7, 2019)

The Telegraph. (2018). More than 900 prosecutions collapse in a year over failure to disclose evidence.

[Online]

Available: https://www.telegraph.co.uk/news/2018/01/24/900-prosecutions-collapse-year-fail ure-disclose-evidence/ (24 ${ }^{\text {th }}$ January 2019)

theconversation.com.

(2017).

[Online]

Available:

http://theconversation.com/good-cop-bad-cop-how-corrupt-police-work-with-drug-dealers-62 
$71\left(5^{\text {th }}\right.$ April 2012)

Theoharis, G. (2007). Social Justice Educational Leaders and Resistance: Toward a Theory of Social Justice Leadership. Educational Administration Quarterly, 43, 221. https://doi.org/10.1177/0013161X06293717

Tonry, M. (2007). 'Foreword'. In: Tyler, T. (ed.), Legitimacy and Criminal Justice: International Perspectives. New York: Russell Sage Foundation.

Trinkner, R., Tyler, T., \& Goff, P. (2016). Justice from within: The relations between a procedurally just organizational climate and police organizational efficiency, endorsement of democratic policing, and officer well-being. Psychology, Public Policy, and Law, 22, 158-172. https://doi.org/10.1037/law0000085

Tyler, T. (2000). Social Justice: Outcome and Procedure. International Journal of Psychology, 35(2), 117-125. https://doi.org/10.1080/002075900399411

Tyler, T. (2003). Procedural Justice, Legitimacy, and the Effective Rule of Law. In: Tonry, M. (ed.), Crime and Justice: A Review of Research. Chicago: University of Chicago Press.

Tyler, T. (2006). Legitimacy and Legitimation. Annual Review of Psychology, 57, 375-400. https://doi.org/10.1146/annurev.psych.57.102904.190038

Tyler, T. (2011). Why People Cooperate: The Role of Social Motivations. Princeton: Princeton University Press. https://doi.org/10.1515/9781400836666

Tyler, T., \& Huo, Y. (2002). Trust in the Law: Encouraging Public Cooperation with the Police and Courts. New York: Russell Sage Foundation.

WalesOnline.

[Online]

Available: http://www.walesonline.co.uk/news/wales-news/no-welsh-police-corruption-pros ecutions-2493963 (March 13, 2019)

WalesOnline.

[Online]

Available: http://www.walesonline.co.uk/news/wales-news/former-detectives-investigated-o ver-alleged-9993260 (June 26, 2019)

WalesOnline.

(2018).

[Online]

Available: https://www.walesonline.co.uk/news/wales-news/dozens-welsh-police-officers-cha rged-14575463 (September 22, 2019)

Walsh, S., White, K., \& Young, R. (2008). Over-Connected? A Qualitative Exploration of the Relationship between Australian Youth and Their Mobile Phones. Journal of Adolescence, 31(1), 77-92. https://doi.org/10.1016/j.adolescence.2007.04.004

Weisburd, D., Greenspan, R., Hamilton, E., Williams, H., \& Bryant, K. (2000). Police Attitudes Toward Abuse of Authority: Findings from a National Study. Washington DC: National Institute of Justice, Washington DC. https://doi.org/10.1037/e523612006-001

Wikström, P., Ceccato, V., Hardie, B., \& Treiber, K. (2010). Activity Fields and the Dynamics 


\section{Macrothink}

Journal of Public Administration and Governance ISSN 2161-7104 2019, Vol. 9, No. 4

of Crime: Advancing Knowledge about the Role of the Environment in Crime Causation. Journal of Quantitative Criminology, 26(1), 55-87. https://doi.org/10.1007/s10940-009-9083-9

Yin, R. (1994). Case Study Research: Design and Methods. London: Sage Publications.

Zedner, L. (2009). Security. London: Routledge. https://doi.org/10.4324/9780203871133

\section{Copyright Disclaimer}

Copyright for this article is retained by the author(s), with first publication rights granted to the journal.

This is an open-access article distributed under the terms and conditions of the Creative Commons Attribution license (http://creativecommons.org/licenses/by/4.0/). 